\title{
夏季静穏日に甲府盆地上で出現する積乱雲の 出現分布と出現前の地上場の特徵 \\ CHARACTERISTICS OF DISTRIBUTION AND PRECEDING SURFACE CONDITIONS OF CUMULONIMBUS CLOUDS APPEARED ON KOFU BASIN ON A CALM DAY IN SUMMER
}

\author{
佐野哲也 1 ・末次忠司 2 ・大石 哲 ${ }^{3}$ \\ Tetsuya SANO, Tadashi SUETSUGI and Satoru OISHI \\ 1正会員 博(理) 山梨大学大学院特任助教 国際流域環境研究センター( ( 4 400-8511 山梨県甲府市武田4-3-11) \\ 2正会員 工博 山梨大学大学院教授 国際流域環境研究センター $($ × 400-8511 山梨県甲府市武田4-3-11) \\ 3 正会員 博(工) 神戸大学教授 都市安全研究センター（广657-8501 神戸市灘区六甲台町 1-1）
}

\begin{abstract}
In summer, localized heavy rainfall in a short time on Kofu Basin is caused by a cumulonimbus cloud. We analyzed the characteristics of distribution and preceding surface conditions of cumulonimbus clouds appeared on Kofu Basin using X-MP radar and surface observation data from July to September in 2012. The frequency of the cumulonimbus clouds appeared on Kofu Basin was low. However, the rainfall amount brought by such a cumulonimbus cloud was large. The first appearance of cumulonimbus clouds concentrated from east side to center of Kofu Basin. Before the appearance of a cumulonimbus cloud, south-southwesterly wind with warmish and moist air from the inlet of the valley on southwest side of Kofu Basin and southeasterly wind with warmish and semimoist air crossing the mountains on east side of Kofu Basin co-existed at surface on Kofu Basin with warm and low moist air. The winds formed the convergence and the airs formed the conditional instability on Kofu basin, which formed the environment of the appearance of a cumulonimbus cloud on Kofu Basin.
\end{abstract}

Key Words : Cumulonimbus cloud, surface conditions, meso- $\beta$-scale environment, Kofu Basin.

\section{1.はじめに}

夏季静穏日に, 都市を含む盆地や平野域では, 積乱雲 に伴う短時間局所豪雨がしばしば発生する.このような 豪雨は，小河川での急激な水位の上昇や流量の増加を生 じさせ，氾濫，冠水などの災害を引き起こす．短時間局 所豪雨を引き起こす積乱雲の出現する時間と位置を予測 するには，メソ队スケール $(20 \sim 200 \mathrm{~km}$ の水平スケール $)$ の 環境場を理解することが重要である.

積乱雲は下層の湿った空気の上層への持ち上げをきっ かけとして出現する. 藤部ら ${ }^{1}$ は, 関東平野上の東京 23 区を例に，夏季高温日午後の短時間強雨に先立つ地上風 系の特徵として, 鹿島灘沿岸からの東寄りの風と相模湾 沿岸からの南寄りの風との東京付近での収束を示した. また，降水系の発生・発達場所はこれらの収束域と対応 寸ることも示した。 中西と原 ${ }^{2}$ は, 東京23区で降水が強 化される日について, 降雨開始の3時間以上前からの, 鹿島灘沿岸からの東寄りの風と相模湾沿岸からの南寄り
の風による強い収束の継続を示した，これらは，海風系 の局地風に伴う収束による上昇流や水蒸気の集中が，積 乱雲の発生・発達に寄与することの重要性を示唆する 盆地において, 谷風循環の発達に伴い, 盆地上空の沈 降流による加熱と山岳への水蒸気輸送が生じる ${ }^{33,4)}$. この ため, 盆地では日照が多く, 午後の驟雨性の短時間降雨 の頻度は少ない傾向にある ${ }^{5}$. その一方で，斉藤と木村9) は, 山岳域ほどではないが, 午後から夕方にかけて盆地 や谷で対流性降水の出現頻度が増加することを示してい る. しかし, 盆地上で積乱雲が出現・発達する地上場や その形成については，十分に理解されていない。

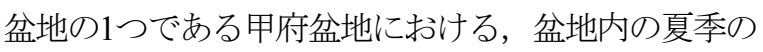
平均的な降雨量は, 周囲の山岳域のそれよりも小さい》。 その様な状況においても, 盆地内で短時間豪雨が出現す ることがあり, 都市の中小河川の水位の急激な上昇をし ばしば引き起こす8). 山梨大学では, 甲府盆地上の山梨 大学甲府キャンパスに，X-バンドマルチパラメータレー ダを設置(以下, UYR)し, 甲府盆地と周囲の山岳で出現 する降水現象の観測を実施している(図-1) $)^{7,9)}$. これまで 


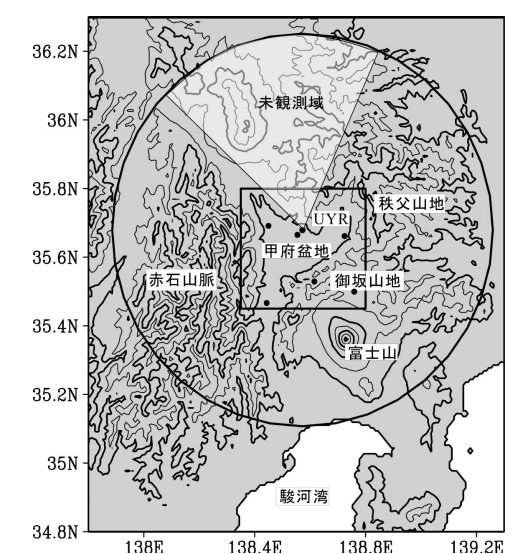

図-1 UYRの観測範囲と地形蓄. 等値線は標高0mから $500 \mathrm{~m}$ 毎の 等高線, 円はUYRの観測範囲, 四角は解析領域を示す。

表-1 夏季静穏日における降水セルの出現日数

\begin{tabular}{|c|c|c|c|}
\hline 対象日数 & 夏季静稳日数 & $\begin{array}{l}\text { 隆水日現日数 } \\
\end{array}$ & 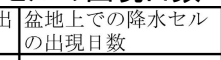 \\
\hline 9 & 60 & 27 & 8 \\
\hline
\end{tabular}

に, 盆地上で出現し短時間豪雨をもたらす積乱雲がいく つか観測された。

本研究では，甲府盆地を例に，盆地上に出現した積乱 雲の出現位置とそれらがもたらした降雨量, そして積乱 雲の出現前の地上場について, UYRと気象庁の地上観測 の結果から解析寸る。 そして観測データの解析結果と気 象庁メソ客観解析から, 積乱雲が盆地上で出現するメソ

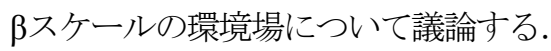

\section{2. 盆地上に出現した降水セルの特徵}

甲府盆地は，約 $40 \mathrm{~km}$ 程度の水平スケールを持ち，東 に秩父山地, 西に赤石山脈, 南に御坂山地と, 標高 1 $2 \mathrm{~km}$ の山地に囲まれ，標高 $500 \mathrm{~m}$ 付近から急激に標高が増 寸急峻な地形を有する(図-1). 本研究において, 標高 500m以下を盆地域，それ以上を山岳域と定義する。ま た, 盆地の南西には谷の入り口があり, 谷は駿河湾沿岸 まで伸びる.

1 つの積乱雲に伴う降水は, 気象レーダによりセル状 エコーとして観測される ${ }^{10)}$. 本研究では, UYRの観測に より高度 $2 \mathrm{~km}$ で観測された反射強度 $\left(\mathrm{Z}_{\mathrm{H}}\right)$ が $40 \mathrm{dBZ}$ 以上の 1 つの極大值を持つセル状エコーを降水セルと定義し，発 達期または成熟期の積乱雲とみなす99.また，UYRによ る降雨量推定はPark et al. ${ }^{11)}$ を参照した.

解析は2012年7月から9月までの92日間を対象とした。 気象庁の日本時間9時00分(0900JST)の地上天気図から， 台風や低気圧，前線など総観規模の擾乱が甲府盆地周辺 に存在しない日を「夏季静穏日」として抽出した. その 中から，1200JSTから2400JSTまでにUYRにより降水セ ルが観測された日を「降水セルの出現日」とした．抽出 した降水セルの出現日の中から，盆地上で出現した日を 「盆地上での降水セルの出現日」として抽出した。 なお, 「盆地上に出現する降水セル」に着目するため, 山岳で 出現した降水セルが盆地一伝搬する事例は解析に含めな
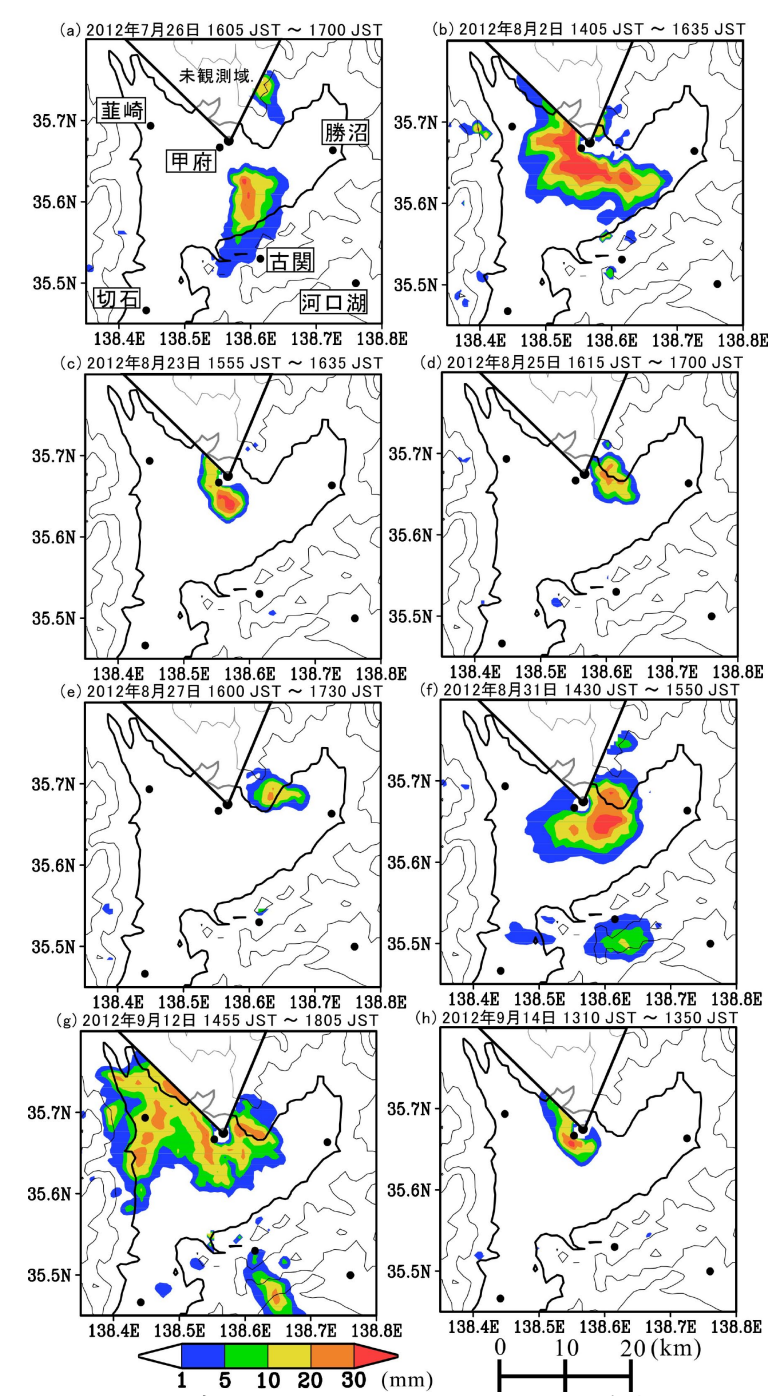

図-2 図-1の四角の領域における, 盆地上での降水セルの出現 日における,UYRで推定された期間積算降雨量. 図中の 黒点は気象庁の地上観測地点を示す.

い. また山岳の降水セルからの外出流に伴い盆地上で出 現した降水セルの事例も対象外とする.

\section{（1）盆地上での降水セルの出現日数}

解析期間中，夏季静穏日数は60日であった(表-1). そ のうち降水セルの出現日数は27日であった. そして, 降 水セルの出現日数のうち, 盆地上での降水セルの出現日 数は8日であった. 盆地域の対流性降雨の出現頻度は山 岳域と比べて小さいことが示されているの. 本事例でも， 盆地域の降水セルの出現日数は山岳域に比べ少ない.

\section{（2）UYRで推定された積算降雨量の特徵}

図-2は，盆地上での降水セルの出現日として抽出され た，それぞれのUYRで推定された積算降雨量とその分布 を示す．降雨域は，8月2日では東から西へ伸び，9月12 日では, 盆地の中央部から北西へ降雨域が広がった(図一 $2 \mathrm{~b}$ と $\mathrm{g})$. 残りの日については, 盆地の東部や中央部で 塊状の降雨域が見られた. 積算降雨量は, いずれの日も 1〜2時間の間に最大で20～30 mm以上に達し，それらは 局所に集中した. 先に述べたとおり, 盆地域上の降水セ 


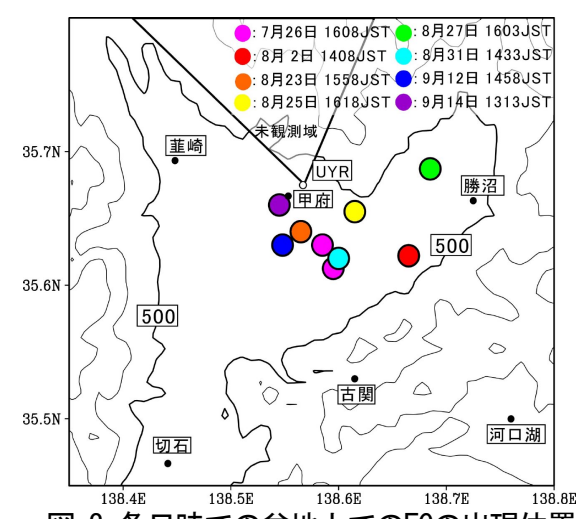

図-3 各日時での盆地上でのFCの出現位置

ルの出現日数は少ない. しかし，ひとたび降水セルが出 現すれば，それが発達し組織化した結果，局所に短時間 で非常に多量の降雨がもたらされた.

\section{3. ファーストセル(FC) の出現特性}

\section{（1）FCの出現分布}

図-3は，UYR観測により盆地上で最初に観測された降 水セルを, 最初に出現した降水セル(以下，ファースト セル，FC)として，各日時の出現位置を示す．8月 2,25 , 27日のFCの出現位置は，盆地東部に散在した。7月26日, 8月23，31日では，気象庁気象観測点「気象官署甲府」 (以下，甲府観測点)の南東側に集中した．9月12，14日で は, 甲府観測点の南側で, 対象としたFCの中で最も西 側に出現した。

\section{（2） FC出現前の平均的な地上の風向風速}

図-4は，盆地上の地上観測点での，FC出現30分前を 平均した風向風速を示す. 盆地の南西の谷の入り口付近 の気象庁アメダス観測点「切石」(以下，切石観測点)で は，南南西風が卓越した. 盆地東部の気象庁アメダス観 測点「勝沼」(以下, 勝沼観測点)では, 南東風が卓越し た．甲府観測点では，盆地東部，また甲府観測点の南東 でFCが出現した7月26日，8月2，23，25，27，31日には， 南西風が卓越した. この風は切石観測点の風と対応する. またもっとも西側でFCが出現した9月12，14日では，南 南東または南東が観測された。これらの風は勝沼観測点 の風と対応する。また気象庁アメダス観測点「菲崎」 (以下，韮崎観測点)では，9月12，14日を除いて，弱い南 南東風が卓越した。一方，9月12日はごく弱い西南西風， 9月14日は強い東南東風であった.

甲府盆地内において, 南西の谷から吹く南南西風と, 盆地東部で吹く南東風が共存するとき, 盆地上で降水セ ルが出現するという傾向が示された，その中で，南南西 風が盆地の中央部に達するとき, 盆地東部や甲府観測点 の南東で降水セルが出現する傾向が見られる. その一方 で，盆地東部の南東風が盆地の中央部に達寸るときには,

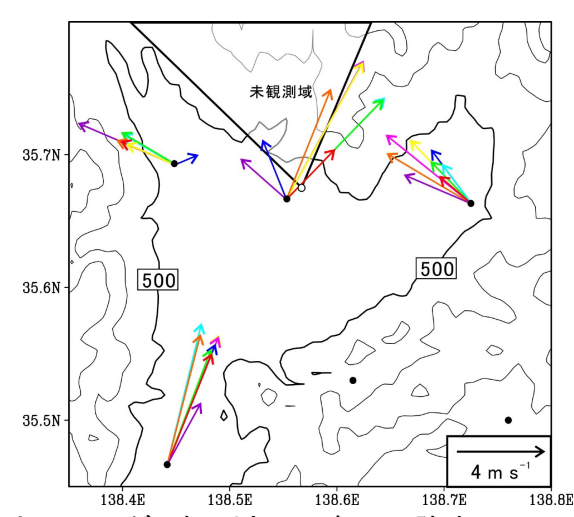

図-4 盆地内のアメダス観測点での各日の降水セルの出現30分 前を平均した風向風速. 凡例は図-3の日付と同じ.

甲府観測点の南側で，より西側に降水セルが形成する傾 向が示唆される.

\section{FC出現前の地上場の時間変化}

盆地上でFCが出現するときに吹く，南西の谷の入り 口からの南南西風と盆地東部の南東風の特徵について, 甲府観測点で南南西風を観測した7月26日と, 南東風を 観測した9月12日を例として，地上場の時間変化を示す．

\section{（1）2012年7月26日の事例}

地上天気図によると，甲府盆地が日本列島の南海上の 高気圧に覆われていたことから，一般風は弱いと言える (図-5a). 0900JSTからFC出現までの風向風速の時間変化 を見ると, 切石観測点では, 1200JST頃に弱い北西風か ら南風に変化し，1310JST以降には強い南南西風となっ た(図-6a). 勝沼観測点では, 弱い西風が継続し, 1430JST以降に南東風が発達した(図-6c). 甲府観測点で は，風向の定まらない弱い風が吹いていたが，1510JST 以降, 南西風と変化した(図-6b). この風系は, 夏季晴天 時の甲府盆地に現れる風系の 1 つある ${ }^{12)}$.

気温と風速の時間変化を見ると, 切石観測点では, 0900JSTから1310JSTまで気温が上昇した(図-7a).その 間, 風速は小さく, 1200JST頃に大きくなり始めた. 1310JST以降には風速はさらに大きくなり，その一方で 気温はやや低下した. 勝沼観測点では, 弱風の状態で気 温が上昇した(図-7c). $35^{\circ} \mathrm{C}$ 付近で気温の上昇が鈍化する が，風速は小さいままであった．1430JST以降には，風 速は大きくなり，気温はわずかに低下した，甲府観測点 では, 勝沼観測点と同様に, 弱風の状態で気温が上昇し た(図-7b). $36^{\circ} \mathrm{C}$ 付近で気温の上昇が鈍化するが，風速は 小さいままであった. 1510JST以降では，風速は急激に 大きくなり，気温はわずかに低下した，風速が小さく， 気温上昇を続ける盆地内に，いずれも風速の大きい，南 西の谷の入り口からの南南西風と, 盆地東部の南東風が 入ることで，盆地内の気温の上昇が抑制される．そして， 南南西風が先に盆地の中央部に達していた. 
(a)

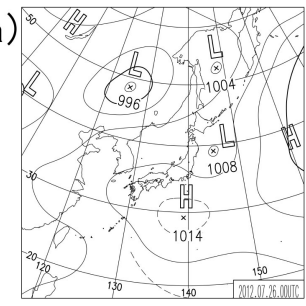

(b)

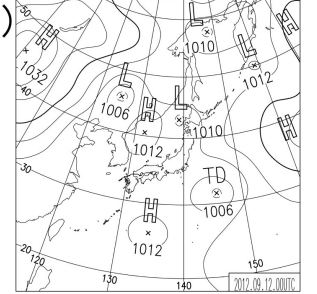

図-5（a) 7月 26日，(b) 9 月 12 日の0900JSTの地上天 気図. (出典: 気象庁)
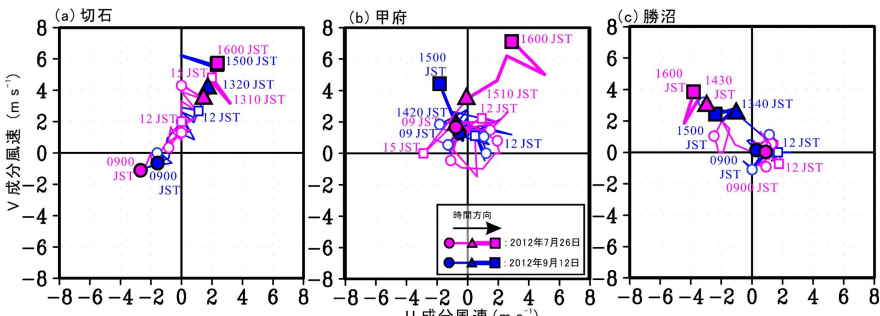

図-6 各地上観測点の風速(U: 東西, V: 南北) の時間変化．時間は09JST からFCの出現時刻まで。 ○は1時間毎, 口は3時間毎に記す。
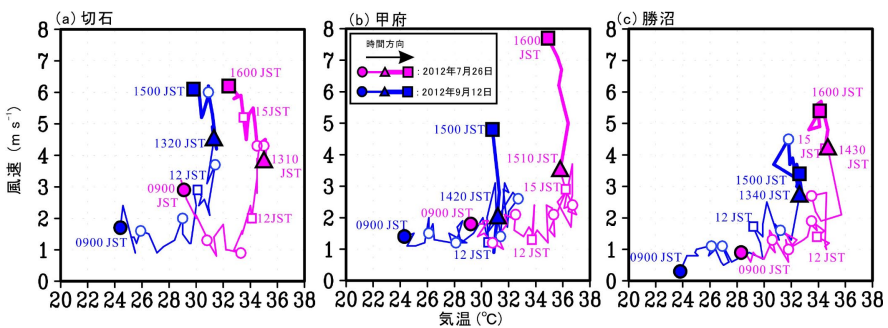

図-7 地上観測点の気温-風速の時間変化. 時間は図-6と同じ，
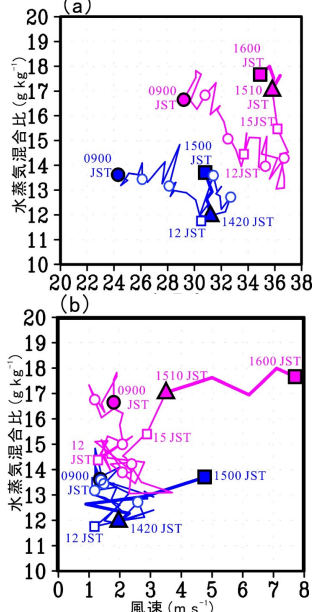

図-8 甲府観測点の (a) 気温-水 蒸気混合比と (b) 風速-水 蒸気混合比の時間変化. 凡例は図-6bと同じ
甲府観測点の気温-水蒸気混合比の時間変化を見ると, 1400JST頃までに気温は上昇し，その一方で水蒸気混合 比は減少した(図-8a). その後1500JST頃までは，36〜 $37^{\circ} \mathrm{C}$ 維持し, 水蒸気混合比はわずかな増減を示した. そして1510JST以降には，気温は $36^{\circ} \mathrm{C}$ 付近を維持する一 方で，水蒸気混合比は急増した．風速-水蒸気混合比の 時間変化を見ると，午前から午後にかけて小さい風速を 維持する中で, 水蒸気混合比は減少した(図-8b). 1510JSTには，風速は大きくなり，水蒸気混合比が急増 した. その後, 高い水蒸気混合比を維持し, 風速も大き くなった. 南西の谷の入り口から吹く南南西風は, 盆地 内の空気よりもわずかに気温の低い，かつ豊富な水蒸気 を含む空気をもたらしていたと言える.

\section{（2）2012年9月12日の事例}

地上天気図によると，日本列島の南東海上に熱帯低気 圧が存在したが，甲府盆地は概ね日本海上に中心を持つ 高気圧に覆われた(図-5b). 切石観測点と勝沼観測点の風 向風速の時間変化は，7月26日の事例と比べてほぼ同様 の変化を示したが，勝沼観測点での南東風の始まる時刻 が早まっていた(図-6a と6c). 甲府観測点でも，1420JST までは，7月26日と同様に風向の定まらない弱い風が吹 いていたが，1420JST以降になると南東風が卓越した(図 -6b). これは太平洋の沖合に低気圧が存在する時に現れ る風系と似ているが ${ }^{12)}$, 総観場の影響を強く受けない一 般風の弱い場で生じた風系と言える。

気温-風速の時間変化において，切石観測点と勝沼観 測点について，7月26日の事例と比較すると，日本海上 の高気圧に覆われたため昇温を停止寸る気温が低いが, ほぼ同様の変動を示した(図-7aと7c)。甲府観測点では, 弱風の状態で気温が上昇した(図-7b). $31^{\circ} \mathrm{C}$ 付近で気温の 上昇が鈍化し，風は強弱を繰り返した。1420JST以降で は，風速は大きくなり，気温はわずかに低下した. 南西 の谷の入り口からの南南西風と盆地東部の南東風により,
盆地内の気温の上昇が抑制された点では，7月26日と同 じであるが，9月12日は盆地の東部で吹く南東風が先に 盆地の中央部に達していた.

甲府での気温-水蒸気混合比の時間変化を見ると, 1200JSTまで気温が上昇する一方で，水蒸気混合比は減 少した(図-7a). 1300JST頃に水蒸気混合比は増加するが, 1400JSTまでに再び減少した. 1420JST以降，水蒸気混合 比は増加し，気温は $31^{\circ} \mathrm{C}$ 付近を維持した。 しかし，水蒸 気混合比の増加は，7月26日と比べて小さい．風速-水蒸 気混合比の時間変化では，午前から午後にかけて小さい 風速を維持する中で，水蒸気混合比は減少した(図-7b). 1420JST以降，水蒸気混合比は増加し，風速も大きく なった. 盆地の東部で吹く南東風は, 盆地内の空気より もわずかに気温の低い，か南南西風によりもたらされ る空気よりもわずかに水蒸気の少ない空気をもたらして いたと言える。

\section{5. 考察}

図-9は，気象庁メソ客観解析より得られた7月26日の $925 \mathrm{hPa}$ 面(高度約 $800 \mathrm{~m}$ 付近)の相当温位上風向風速，水平 収束の時間変化を示寸，甲府盆地内では，0900JSTから 1200JSTにかけて，相当温位は大きな変動を示さなかっ た(図-9aと9b). 風は東風から南東風に変化したが，風速 は小さいままであり, かつ発散場となった。これらは, 甲府観測点での午前から午後にかけての気温の上昇と水 蒸気混合比の急激な減少，そして盆地内の観測点の風向 風速と対応する. 混合層の発達や谷風循環に伴う沈降流 による加熱と山岳への水蒸気輸送により, 盆地内は高温 かつ低圧となり，水蒸気は減少したと考えられる3),4).

1200JSTから1500JSTにかけて，高相当温位域を伴う南 寄りの風が，駿河湾側から盆地の南西の谷を通り，盆地 に入り込む(図-9bと9c). 南西の谷を通る線分B-B'の温位, 


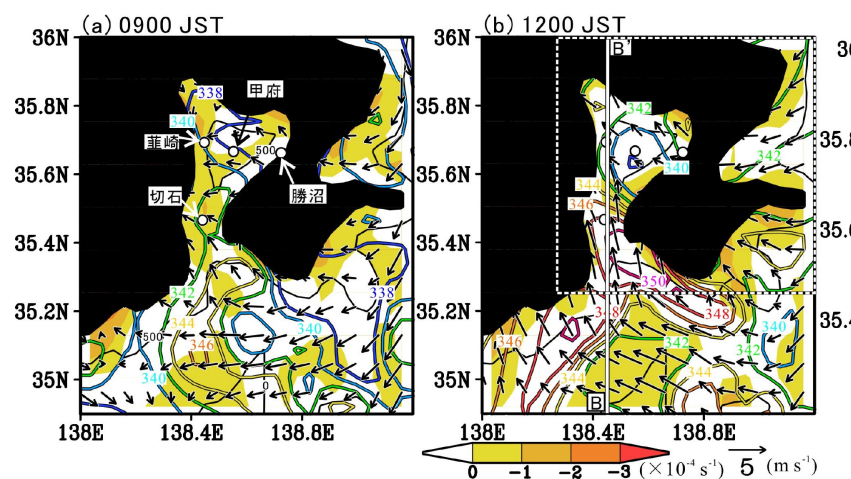

図-9 気象庁メソ客観解析で得られた7月26日の $925 \mathrm{hPa}$ 面の相当温位 (カラ一の等値線, $2 \mathrm{~K}$ 毎) と風向風速 (矢印), 水平収束 (カラ一の陰影) の時間変化. 黒色の等值線はメソ客観解析 で用いた地形の等高線 $(0 \mathrm{~m}, 500 \mathrm{~m})$, 黒色の陰影は標高 $800 \mathrm{~m}$ 以上の地形, 白丸は実際の緯 度経度の気象庁地上観測点を示す.

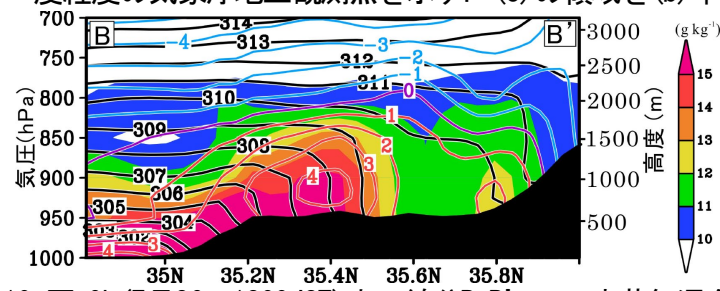

図-10 図-9b(7月26日1200JST) 中の線分B-B' での水蒸気混合比 (カラ一の陰影) と温位(黒色の等値線, $1 \mathrm{~K}$ 毎)，南北成 分の風速の鉛直分布 (カラ一の等値線, $1 \mathrm{~m} \mathrm{~s}^{-1}$ 毎, 断面 内の風速(左から右への速度を正)。黒色の陰影はメソ客 観解析で用いた地形を示す.

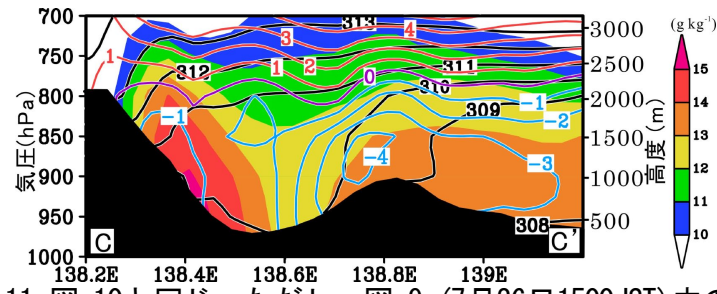

図-11 図-10と同じ. ただし, 図-9c(7月26日1500JST) 中の線 分C-C’についてである.

水蒸気混合比，南北風速の鉛直断面図を見ると， $35.2^{\circ}$

$\mathrm{N}$ か $35.5^{\circ} \mathrm{N}$ でで, $950 \mathrm{hPa} ら 850 \mathrm{hPa}$ の高度にて温 位の減少と大きい水蒸気混合比，そして強い南寄りの風 が見られる(図-10).これらは，切石観測点での気温の低 下と南南西風の発達, 甲府観測点での気温の低下と水蒸 気混合比の増加, そして南南西風の発達に対応する(図一 $6,7,8)$. 静岡側の山岳の南側斜面と駿河湾との間で発達 する熱的局地循環に伴う南寄りの風により，高度 $800 \mathrm{~m}$ 付近での駿河湾側の水蒸気の多い空気が，谷を通り盆地 内一進入したと考えられる99.

1500JSTの盆地の東側では，駿河湾側からの南寄りの 風と比べてやや低い相当温位域を伴う東寄りの風が吹く (図-9c). 盆地と東側の山地を通る線分C-C'の鉛直断面図 を見ると, 山岳を越えて盆地一進入する厚さ約 $1 \mathrm{~km}$ 程 度のやや低い温位，やや大きい水蒸気混合比そして東寄 りの風が見られる(図-11)。これは, 勝沼観測点での気温 の減少と南東風の発達と対応する(図-6と7). 山の高さが 概ね混合層高度と同程度，またはそれ以下のときには， 山岳を越える局地風が発達できる ${ }^{3), 13)}$. 山岳を越えてき た南東風により，温位のやや低い，かつ水蒸気のやや多 い空気が，盆地内に進入したと考えられる. (c) $1500 \mathrm{JST}$

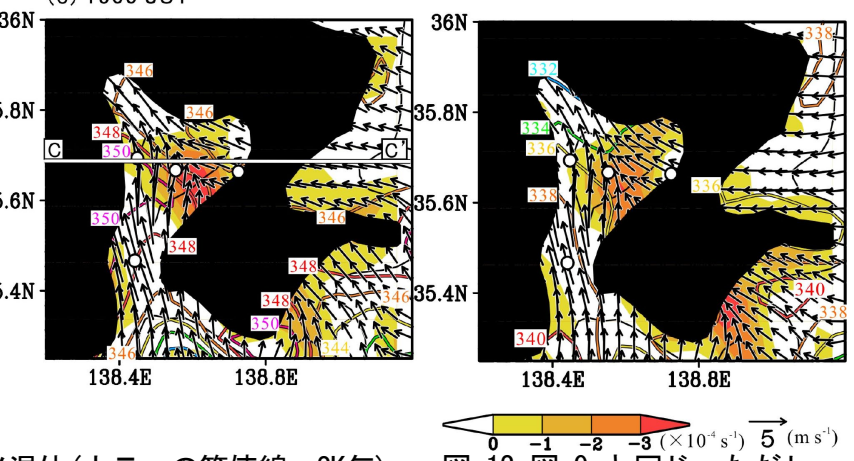

図-12 図-9cと同じ. ただし, 日時は9月12日1500JSTで ある.

7月26日では，FCは甲府観測点の南東側で出現し，出 現前には甲府観測点で南南西風, 勝沼観測点で南東風で あった(図-3と4). 同日1500JSTの925hPa面のメソ客観解 析から, 盆地の中央部で南南西風と南東風による水平収 束が解析された(図-9c). 一方，2012年9月12日では，FC は7月26日と比べて西側で出現し, 出現前には甲府, 勝 沼両観測点では南東風であった(図-3と4). 同日の 1500JSTの925hPa面のメソ客観解析から, 南南西風と南 東風による水平収束域が解析されたが，7月26日と比べ てわずかにやや南西に広がり，かつ南南西風に伴う高相 当温位の空気は盆地内に到達していなかった(図-12). ま た観測データの解析から, 南南西風と南東風が盆地内で 共存したにもかかわらず，盆地内でFCが出現しなかっ た事例が12日あり, 南南西風に伴う空気の水蒸気混合比 が小さかったこと, 南東風が南南西風の到達よりも早い 時間に甲府盆地を覆ったことを確認している(図なし).

以上から, 混合層の発達や熱局地循環に伴い, 高温か つ低圧化，そして水蒸気が減少した盆地内に，駿河湾側 から南西の谷を通る南南西風に伴う高相当温位の空気, そして盆地東側の山岳を越える南東風に伴うやや高い相 当温位の空気が進入し, 条件付不安定の場が形成したと 考えられる. そして, 南南西風と南東風により盆地内で 水平収束が形成され, FCの出現する場の形成に寄与し たと考えられる. また, 南南西風に伴う高相当温位の空 気の盆地への到達がFCの出現に必要であると言える. その南南西風に対する南東風の進入の時期により， FC の出現位置が変化したと考えられる.

このように，盆地上のFCの出現は，盆地内外のメソ $\beta$ スケールの気象の影響を受けると言える.ここで, 盆地 上のFCの出現の予測に向けた盆地内の環境場の監視に ついて議論する. 切石観測点の南南西風(図-6aと7a)と勝 沼観測点の南東風(図-6cと7c)がFC出現の約1時間30分か ら3時間前に，そして甲府観測点の南南西風あるいは南 東風の到達とそれに伴う気温と水蒸気混合比の変動(図一 6b, 7b, 8)がFC出現前の約40分から1時間前に観測された ことから，約1 3時間のリードタイムでFCの出現前の盆 地内の環境場の推定が可能と考えられる. また国土地理 
院のGPS受信機が複数設置されていることから ${ }^{14)}$, 可降 水量の推定を通して詳細な条件付不安定場の推定も可能 になると考えられる．しかし，地上観測点やGPS観測点 が密でないため、収束と可降水量の分布の十分な算出は 見込めず，FCの出現位置の推定を難しくする．レーダ による降水セルの観測に加え, 盆地内外の時空間的に密 な風と水蒸気の観測の強化が, 降水セルの出現前の盆地 内の環境場の監視の充実化につながると考えられる.

\section{6. まとめ}

甲府盆地上に出現した積乱雲の出現位置とそれらがも たらす降雨量が解析された. 2012年7月から9月まで, 静 穏日に甲府盆地上で積乱雲が出現したのは8日であった が。いずれも出現した積乱雲は発達・組織化に伴い, 局 所に1 2時間で最大で20 30 mmの降雨をもたらした．盆 地域での積乱雲の出現頻度は小さいが，ひとたび出現す れば豪雨をもたらす可能性が十分にあることが示された。 盆地上で出現する積乱雲の最初の出現位置と出現前の 地上風の傾向が解析された。積乱雲は, 盆地内に南西の 谷からの南南西風と, 盆地の東部の南東風が共存すると きに出現する傾向を示した. 積乱雲の最初の出現位置は, 甲府観測点で南南西が観測された事例では盆地の東部か ら中央部に集中した。一方, 南東風の場合, 積乱雲の出 現はより西側に位置した. 事例解析から, 南南西風は, 盆地内の空気と比べて気温はわずかに低く，水蒸気の多 い空気を伴うことが分かった。一方南東風は, 盆地内の 空気と比べて気温はわずかに低く, 南南西風に伴う空気 と比べて水蒸気のやや少ない空気を伴うことが示された。

観測事実を基に，気象庁メソ客観解析を用いて甲府盆 地上で積乱雲が出現する環境場を考察した，混合層の発 達や熱局地循環に伴い，高温かつ低圧化し，水蒸気が減 少した盆地内に，高度約 $800 \mathrm{~m}$ 付近の駿河湾側からの南 南西風に伴う豊富な水蒸気を含む高相当温位の空気と, 盆地東部の山岳を越える南東風に伴うやや高い相当温位 の空気が入り込むことで, 条件付不安定の場が形成され たと考えられる. そして, 南南西風と南東風とで形成す る収束が積乱雲の出現する場の形成に寄与すること, 南 南西風の盆地一の進入に対する南東風の進入の時期によ り, 積乱雲の出現位置が変化すると考えられる.

本研究において，一部ではあるが，盆地上での出現す る積乱雲の頻度とそれらによる降雨の実態, 積乱雲の出 現前の盆地内の環境場の形成が示された. 盆地内外を対 象としたメソ 突発的な短時間局所豪雨をもたら寸積乱雲の出現の要因 解明と予測精度の向上が期待できると考えられる.

謝辞 : 本研究は, 山梨大学グローバルCOEプログラム 「アジア域での流域総合水管理研究の展開」による支援
を受けました。また，社会システム改革と研究開発の一 体的推進「気候変動に伴う極端現象に強い都市創り」か ら一部支援を受けました．記して感謝の意を表します。

\section{参考文献}

1) 藤部文昭, 坂上公平, 中鉢幸悦, 山下浩史: 東京23区における 夏季高温日午後の短時間強雨に先立つ地上風系の特徴, 天気, 第49巻, pp.395-405, 2002.

2) 中西幹郎, 原由紀男: 東京都市部に短時間強雨をもたらした 降水系の降雨強化に結びつく局地風の特徴, 天気, 第50巻, pp.91-103, 2003.

3) Kimura, F. and T. Kuwagata: Thermally Induced Wind Passing from Plain to Basin over a Mountain Range, J. Appl. Meteor., Vol.34, pp.1538-1547, 1993.

4) Kimura, F. and T. Kuwagata: Horizontal Heat Fluxes over Complex Terrain Computed Using a Simple Mixed-Layer Model and a Numerical Model, J. Appl. Meteor., Vol.36, pp.549-558, 1995.

5) Kuwagata, T.: Structure, An Analysis of Summer Rain Showers over Central Japan and its Relation with the Thermally Induced Circulation, J. Meteo. Soc. Japan., Vol.75, pp.513-527, 1997.

6) 齋藤智興, 木村富士男: 中部関東域における夏期の対流性降 水の日変化, 天気, 第45巻, pp.541-549, 1998.

7) 佐野哲也, 大石哲, 中村高志, 砂田憲吾: X-バンドMPレーダ 観測による盆地を囲む山岳斜面での降雨分布と降雨堌幅機構 の解析, 土木学会論文集B1(水工学), 第68巻, pp.I_355-I_360, 2012.

8) Hapsari, R. I., S. Oishi, K. Sunada and T. Sano: Improving Flood Simulation in Urban River Basin Using X-Band Polarimetric Radar and Distributed Hydrological Model, Annual Journal of Hydraulic Engineering, Vol.54, pp.121-126, 2010.

9) Sano, T., S. Oishi and K. Sunada: Structure, Maintenance and Development of a Stationary Convective System Generated over a Mountain Slope Adjoining a Bay in Summer, J. Meteo. Soc. Japan., Vol.90, pp.807-831, 2012.

10) 石原正仁: 2008 年雑司が谷大雨当日における積乱雲群の振舞 いと局地的大雨の直前予測I-3次元レーダーデータによる積 乱雲群の統計解析-, 天気, 第59巻, pp.549-561, 2012.

11) Park, S. G., M. Maki, K. Iwanami, V. Bringi and V. Chandrasekar: Correction of radar reflectivity and differential reflectivity for rain attenuation at X band. Part II: Evaluation and application, J. Atmos. Oceanic. Technol., Vol.22, pp.1633-1655, 2005.

12) 神田学, 角井充: 甲府盆地における夏季晴天の風系および気 温分布の解析, 天気, 第42巻, pp.763-771, 1995.

13) Kurita, H., H. Ueda and S. Mitsumoto: Combination of Local Wind Systems under Light Gradient Wind Conditions and Its Contribution to the Long-Range Transport of Air Pollutants, $J$. Appl. Meteor., Vol.29, pp.331-348, 1990.

14) 国土地理院, 日本列島の地殼変動, http://mekira.gsi.go.jp/, 2013年9月28日閲覧.

(2013. 9. 30受付) 